\title{
Könyvszemle
}

SIPOS JÚLIA GONDOZÁSÁBAN

\section{KI A FILOZÓFUS? MAGYAR FILOZÓFIATÖRTÉNETI TANULMÁNYOK}

A Perecz László közelmúltban megjelent írásainak válogatását tartalmazó könyv anyagát tematikusan egy laza szál köti össze: valamilyen módon mindegyik kapcsolódik a magyar filozófia társadalmi/közéleti funkciójának, a filozófus társadalomban betöltött szerepének kérdéséhez. A szerző által ciklusoknak nevezett fejezetbeosztások a könyv gerincvázát adó ezen témakörnek egyes aspektusait járják körül.

A rövid előszó utáni bevezető írás egy könnyed hangvételü instrukció azok számára, akik netán azt tervezik, hogy a magyar filozófia történetével foglalkozzanak. Legalábbis első olvasatban; értelmezhető úgy is, mint ironikus hangú látlelet, mely az irodalom és a filozófia társadalmi beágyazottságának különbségeit, és - ezzel összefüggésben - a magyar filozófiatörténet müvelésének sajátosságait, nehézségeit illusztrálja. Tanácsot is ad - bár kissé humoros formában -, hogyan kovácsoljon a hátrányból előnyt a tárgykör (leendő) kutatója.

A következő cikk a magyar filozófiatörténet vonatkozásában toposszá vált elmaradottság-diskurzus vonatkozásában idéz meg négy - a filozófia mint diszciplína institucionalizálódása szempontjából is különböző korszakokat reprezentáló - gondolkodót. Almási Balogh Pál, Alexander Bernát, Sándor Pál és Balogh István filozófiai elmaradottságunkra, a magyar filozófia epigonizmusára reflektáló írásait egymás mellé állítva láthatóvá válik, ki hogyan diagnosztizálja korának helyzetét, miben látja az elmaradottság okát, és milyen javaslatokat fogalmaz meg a kedvezőtlen állapot megváltoztatására. Az ezen fejezetbe tartozó másik írás témája jelenünkhöz áll közelebb: a 2011-ben indult, filozófusokkal szembeni sajtótámadásokra tekint vissza, az aktuálpolitikai vonatkozásokat szándékoltan háttérben tartva.

A harmadik blokk két írása a filozófusnak a magyar kultúrában betöltött szerepét néhány konkrét szereplő esetét alapul véve vizsgálja. Az első cikk a filozófia és az irodalom társadalmi beágyazottsága különbségeinek felvázolása után Bessenyei György példáján keresztül mutatja meg, hogyan csapódik le ez a viszony a különböző szellemi tevékenységformát - filozófiát, illetve szépirodalmat - müvelő szerzők befogadása során, s hogyan kanonizálódik végül is íróként a mindkét területre tartozó produktumokat létrehozó Bessenyei. A cikk felvázolja, hogy a 
szigorú teoretikus stílusú filozófia általi hatásgyakorlás nehézségei, a szélesebb olvasóközönséghez való eljutás lehetetlensége miatt jut maga Bessenyei is arra a következtetésre, hogy a befogadhatóság érdekében engedményeket kell tennie, $\mathrm{s}$ a túl elvont, tudományos stílusú filozófia helyett a könnyen érthető irodalmias formát érdemes alkalmaznia. A cikk Bessenyeit olyan szerzőként - sőt kulcsszereplöként - mutatja be, aki reprezentánsa annak a folyamatnak, melynek során a filozófiátlan - vagy a filozófiához kimondottan ellenségesen viszonyuló - társadalomban a filozófus szépíróvá alakul át.

A filozófusszerepet tárgyaló blokk másik írásának szereplöi Bessenyei mellett Szontagh Gusztáv és Litkei Tóth Péter. Szontagh - számos eltérő foglalkozás- és tevékenységformát kipróbálva - végül filozófusként határozza meg önmagát, de az általa vállalt szerep nem egy szüken értelmezett filozófusszerep. Nem egy komplex elméleti rendszer megalkotásának a vágya hajtja; az akadémikus jellegü munka mellett a filozófuslét részeként tekint a gyakorlatias, társadalmi, kritikai tevékenységformákra. Litkei Tóth megfogalmazásai azt sejtetik, hogy szemében a filozófus tevékenysége magasabb státusszal bír, mint a költőé, ám - ennek költői hangú kinyilvánításán túl - nincsenek jelei egy alaposan végiggondolt, kinyilvánított álláspontjának következményeit is komolyan vevő filozófus-attitüd megvalósítására való törekvésnek. Perecz konklúziója szerint a filozófuslét „Bessenyei számára szerepkeresés, Szontagh számára szerepalakítás, Litkei Tóth számára szerepjáték".

A következő ciklus Böhm Károly és Alexander Bernát filozófiájával foglalkozó cikkel indul. A pozitivizmus és a neokantianizmus együttes hatásának kitéve alkotó - s ezeket összeegyeztetni törekvő - filozófusok egyaránt a nemzeti elkötelezettségủ filozófia megteremtésével próbálkoznak. Bár mindketten szeretnék a filozófiát a tágabb értelemben vett magyar kultúra szerves részévé tenni, ennek mikéntjét illetően már más-más elképzeléseik vannak. Böhm inkább autonóm magyar filozófiát preferálna, Alexander nagyobb szerepet szánna a jelentős külföldi irányzatok meghonosításának.

A filozófusi attitűd egyik aspektusát - konkrétabban a valamely iskola iránti elkötelezettséget, vagy épp az irányzatok váltogatását - négy filozófus példáján mutatja be a következő esszé. Az elkötelezettséget szigorúan vevő hozzáállást illusztrálja a pozitivista Pauer Imre és a neokantiánus axiológiát képviselő Tankó Béla felfogása. Somló Bódog és Pauler Ákos pedig a filozófiai „utazók”, akik alapvető kérdésekben is többször változtatják álláspontjukat. Perecz végül nem mond ítéletet, $\mathrm{s}$ az eredeti álláspontját feladó, azt (akár többször is) másikra cserélő filozófusi magatartást nem marasztalja el, hanem kimondottan - talán túlságosan is - jóindulatúan interpretálja. A következetlenséget látszólagosnak, egy mélyebb, másfajta következetességet hordozónak sejteti.

Az Athenaeum filozófiai folyóirat (1892-1947) történetét tárgyaló, a szerkesztő- és irányváltásokat számba vevő írás négy korszakra bontja a lap működését, 
s vázolja az egyes intervallumok főbb sajátosságait. A lap fennállása során zajló történések filozófiai aspektusai mellett az irányváltások társadalmi-politikai vonatkozásai is szóba kerülnek.

A filozófia institucionális rendszerének alakulását vizsgáló tanulmány első néhány oldala - bár az alcím az 1945 utáni időszakot jelzi mint vizsgált periódust - az intézményrendszer kialakulásának a 17. század közepére tehető indulását, majd annak további alakulását vázolja fel. Az 1945 utáni időszakot a szerző három, egymástól markánsan elkülöníthető szakaszra bontva tárgyalja. A háború utáni koalíciós éveket a kommunizmus, azt pedig a rendszerváltás utáni időszak követi. Ez utóbbi szakasz napjainkig tartó jellemzése alapján is levonható a következtetés: bizonyos pozitív eredmények ellenére az akadémikus intézménystruktúra múködése jelenünkig sem volt képes a filozófia társadalmi elismertségét és beágyazottságát a magyar kultúra egyéb (humán) területeihez és tudományágaihoz hasonló szintre emelni.

Az utolsó ciklus recenziógyüjtemény. Bár az e célra kiválasztott könyvek tematikailag filozófiai vonatkozásokat is hordoznak, nem mindegyik tartozik a szorosabb értelemben vett filozófia területére: szépirodalmi és történelmi témájú müvek ismertető bírálatai is vannak köztük.

A könyv olvasása közben, illetve egészét áttekintve az olvasóban felmerülő kritikai észrevételek egy részének a szerző már preventíve elveszi az élét. Mégpedig azáltal, hogy maga hozza szóba. Az előszóban közli, hogy a cikkek egymástól függetlenül íródtak, s ennek következtében átfedésekkel, ismétlődésekkel találkozhatunk. Ezek miatt előzetesen az olvasó elnézését kéri. Noha annak számára, aki a cikkeket egymás után olvassa, ez megtöri a folyamatosság ívét, mégsem ez a könyv zavaró sajátossága, hanem a müfaji heterogenitás. Noha az írásokat tematikailag összekötő szál - ez a filozófia és a filozófus társadalomban betöltött szerepének kérdésköre - megteremti a kapcsolatot a cikkek között, ám a tárgyalásmód nagyon különböző: zavaró módon váltják egymást az igényesen kivitelezett filozófiatörténeti szakcikk, a lazább szerkezetủ esszéisztika és a (nem érvelö, emocionális töltetü) publicisztika. (Ez utóbbira példa a könyv címét is adó írás, melyben a szerző - noha álláspontja mellett érvelhetne is - nem az argumentatív formát választja.) Nézőpont kérdése, hogy ez a müfaji keveredés baj-e, avagy sem. A szaktanulmányok iránt érdeklődő olvasó - mint amilyen a jelen könyv recenzense - számára legalábbis némileg zavaró, mivel elsősorban - és általánosságban véve is - a szaktanulmányok azok, amelyek rendelkeznek azokkal a teoretikus ,értékekkel” (például alaposság, szakszerüség, tudományosság), ami indokolja a kötetben való (újra)megjelentetésüket.

A borítón, a könyv címe alatt szereplő „magyar filozófiatörténeti tanulmányok" megjelölés olvastán a téma iránt érdeklődő olvasó - legalábbis első körben - kissé másra gondolhat. A megszokottabb, az adott szerző(k) filozófiai nézeteit rekonstruáló, összegző, elemző és/vagy kritizáló tanulmányforma helyett 
e könyvben - ahogy már volt szó róla - a filozófia társadalmi viszonyait középpontba helyező, szociologizáló tárgyalásmóddal találkozunk. (Talán a Böhm és Alexander filozófiáját tárgyaló írás áll legközelebb egy szokványos filozófiatörténeti tanulmányhoz.) Mivel a kötet néhány írása bevallottan nem szaktanulmány, ezért csak némi fenntartással mondhatjuk, hogy a könyvet az alcímként szereplő műfaji meghatározásból fakadó elvárással kézbe vevő olvasó azt kapja, amit várt.

Az előszót illetően még egy apró megjegyzés: a szerző a filozófusnak (és a filozofálásnak) két módját különbözteti meg: a szó egyik értelmében minden gondolataiba mélyedt ember filozófusnak mondható, aki a maga módján keres válaszokat egzisztenciális kérdéseire. Ettől eltérő, szigorú - mondhatjuk úgy is, hogy akadémikus - értelemben a filozófia ,azokra a bizonyos egzisztenciális kérdésekre adott reprezentativ válaszkísérletek kanonizált hagyományát jelenti”. (Kiemelés az eredetiben.) Noha ennek a szövegrésznek csak az a funkciója, hogy a szerző jelezze, hogy az általa tárgyalt filozófusok leginkább valahol a két szélső pólus - a filozófusként értett átlagember vs. az elismert, „,nagy” filozófus - között helyezendők el, egy szempontból mégis kifogásolható. Noha a kanonizált filozófiákról szólva - némileg szűkítve a kört - elsősorban az európai bölcseletről beszél, a megfogalmazás egy további, nem jelzett szúkítést is tartalmaz. Azt sugallja, mintha a filozófia általában véve egzisztenciális kérdésekre keresné a választ. Nem tudni, hogy a szerző azt akarja-e ezzel állítani, hogy az egzisztenciálfilozófia (valamelyik változata) lenne a filozófia mủvelésének adekvát módja, avagy csupán azt az enyhébb tézist, hogy a filozófiai problémák (is) végső soron - valamiféle eredendő genezisüket tekintve - ilyen jellegű problémákban gyökereznek. Mindenesetre ez a jellemzés figyelmen kívül hagyja az ismeretelmélet-centrikus - és esetleg az életproblémákat teoretikusan irrelevánsnak is tekintő - filozófiai felfogásokat.

Ahogy a könyv bemutatóján a szerző távolabbi terveiről szólva elmondta, ,a filozófiai tudás szociológiájára vonatkozó munkát” tervez írni. Már a jelen könyv írásainak többsége is ide sorolható, s ezek szerint a szerzőtől a jövőben szociologizáló stílusban fogant olvasnivalóra (is) számíthatunk.

(Perecz László: Ki a filozófus? Magyar filozófiatörténeti tanulmányok [A magyar nyelvü filozófiai irodalom forrásai XV]. Kolozsvár-Szeged: Pro Philosophia Kiadó-SZTE Klebelsberg Könyvtár Társadalomelméleti Gyüjtemény, 2017)

Holovicz Attila

PhD, filozófus, Miskolc 